\title{
Forewarning of incidence of Spodoptera litura (Tobacco caterpillar) in soybean and cotton using statistical and synoptic approach
}

\author{
N. CHATTOPADHYAY, R. BALASUBRAMANIAM, S.D. ATTRI ${ }^{1}$, KAMALJEET RAY ${ }^{2}$, \\ GRACY JOHN, S. KHEDIKAR and C. KARMAKAR
}

\author{
Agricultural Meteorology Division, India Meteorological Department, Pune, India \\ ${ }^{1}$ India Meteorological Department, Mausam Bhavan, New Delhi \\ ${ }^{2}$ Ministry of Earth Sciences, Prithvi Bhavan, New Delhi
}

Email:nabansu.nc@gmail.com

\begin{abstract}
A study on the effect of weather parameters on the the population dynamics of Spodoptera litura (S.litura) in soybean and cotton during kharif season using six years pest data (pheromone trap catches) at Niphad and Rahuri in Maharashtra showed that rainfall two weeks prior, Tmax and Tmin during the week of incidence signifiantly contributed towards the occurrence of S.litura in soybean. Maximum temperature and morning humidity during the week and one week prior were found to be favourable for the incidence of $S$. litura in cotton. Temperature (maximum: $26-27^{\circ} \mathrm{C} \&$ minimum: $21-22^{\circ} \mathrm{C}$ ), morning relative humidity (above $90 \%$ ) and rainfall during one week prior were found to be congenial weather parameters for the outbreak of the pest in soybean. Similarly, maximum temperature around $32-33^{\circ} \mathrm{C}$, minimum temperature around $22-23^{\circ} \mathrm{C}$, morning relative humidity around 90 per cent, sunshine hours about 4 hrs day ${ }^{-1}$ and rainfall during the previous 2 weeks favoured heavy incidence of S.litura in cotton crop during flowering to boll formation stages. It is also shown how the incidence of S.litura in soybean and cotton can be predicted well in advance using the observed relationship of the pest with weather parameters as well as weather forecast.
\end{abstract}

Key words : Spodoptera litura, soybean, cotton, weather parameters, correlation analysis and Weather forecast.

Soybean is a major oilseed crop and cotton is an important fiber crop in India. The major soybean producing states in the country are Madhya Pradesh, Maharashtra, Rajasthan, Uttar Pradesh, Karnataka and Gujarat. The low productivity of soybean both at national and state levels is attributed to number of biotic and abiotic stress factors like drought, weeds, insect pests and diseases. Among these, insect pests often pose a serious threat to soybean production and increase the cost of cultivation and impair quality of produce in many ways. Out of them, Spodoptera litura (Tobacco caterpillar) is one of the serious defoliators of soybean. It reduces crop value both quantitatively and qualitatively. Incidence of $S$. litura in all the soybean growing parts in Maharashtra, north Karnataka and Madhya Pradesh during kharif season was frequently observed in recent past. Like soybean, insect pests contribute significantly towards limiting the production of cotton in Maharashtra. The newly hatched larvae of S. litura cause heavy damage to flowers, flower buds and bolls by eating their contents. They bore into the bolls often with the hind part of the body exposed outside the boll. The infested bolls and flower buds drop prematurely. It has been estimated that a single larva can destroy about 3-4 buds each day and 7-8 larvae and kill one adult plant. In the absence of bolls and buds, larvae start feeding on leaves.

A number of studies on the sensitivity of weather parameters on the incidences of S.litura on different crops were studied by different workers in the country. Kulkarni (1989) observed significant positive relationship between weekly moth catches and temperature and humidity. Senapati et al. (1990) studied the relationship between pheromone trap catches of S.litura in soybean and weather parameters in West Bengal during 1986 to 1988 and found that maximum temperature was an important weather parameter for population build up of the pest. Selvaraj et al. (2010) conducted studies at five different dates of sowing on three varieties of cotton in Tamil Nadu to ascertain the effect of ecological factors on incidence and development of S.litura They found that the population of pest was built up progressively from April ( $1^{\text {st }}$ week $)$ and acquired its peak in the month of May ( $1^{\text {st }}$ week). According to them, primarily maximum, humidity and sunshine hours combinely faoured 
the incidence of the pest. Mishra et.al. (2013) developed a GIS based Decision Support System (DSS) to predict the pest infestation of S.litura on soybean using weather based prediction rule. Prediction criteria (severe, moderate or low) were developed based on satisfaction of number of weather parameters like temperature, humidity. Jha et.al. (2016) developed an ordinal logistic regression model for predicting the severity of S.litura on groundnut. Sharma et.al (2017) established relationship between weather parameters and S.litura infestion on sugarbeet and Nandagopal et.al (2006) studied the population dynamics of this leaf eating caterpillar in relation to weather parameters in groundnut in South Saurashtra region. The crop pest forewarning models help agriculturists to identify the severity level of pest population on crops based on weather data in a crop season. It also helps farmers for taking timely and appropriate management practices and also to avoid unnecessary spraying of pesticides.

An attempt has been made in this paper to find out the effect of weather parameters on incidence of S.litura and also to predict the occurrence of the pest using statistical and synoptic methods for predicting the outbreak of this pest for taking appropriate prophylactive measure operationally to control the damage of the pest on soybean and cotton respectively at Niphad and in cotton at Rahuri in Maharashtra.

\section{MATERIALS AND METHODS}

The quantitative pest data for S.litura infestation in soybean was collected for 6 years (2009-2014) at Agricultural Research Station (ARS), Niphad and on cotton at Mahatma Phule Krishi Vidyapeeth (MPKV) Rahuri (2004-2009). The soybean crop at Niphad was sown around Standard Meteorological Weeks (SMWs) 27 to 30 ( $6^{\text {th }}$ July to end of July) and harvested around SMW 41(second week of October). Sowing of irrigated cotton crop at Rahuri was carried out during SMW 15-16 (middle of April) and picking was started by SMW 43 (end of October).

A total of five pheromone traps for S.litura were installed at four directions (East, West, South and North) and one in the middle of one acre untreated field at Auxiliary Evapotranspiration (AET) station, Rahuri and ARS Niphad. The traps were installed 5 feet inside the crop from the boundary of the field and were fixed to bamboo 1.5 feet above the crop height. Pest observations were recorded daily on one block of control experimental plot where insecticides and pesticides were not used during the entire period of crop growth. Weekly average population of the pest was used for the study. The weekly meteorological parameters viz., rainfall (RF), maximum temperature (Tmax), minimum temperature (Tmin), morning relative humidity (RHI), evening relative humidity (RHII) and Bright Sunshine Hours (BSSH) for different SMW during the entire crop period for all the years of study were obtained from the National Data Centre, India Meteorological Department (IMD), Pune. Information on weather forecast were collected from the Weekly Weather Reports and synoptic charts prepared by the Weather Forecasting Section, IMD, Pune.

Both statistical tools and graphical superimposition techniques were used to find out the inter relationship between the pest population and meteorological parameters.

Correlation analysis was carried out between the pest population and meteorological parameters. Correlation analysis between pest the population and weather parameters for the current week as well as at four weeks lag period was carried out. The correlation analysis was carried out between the pest population and meteorological parameters for the years 2009-2014 for soybean at Niphad, 2004-2009 at Rahuri for cotton. Student's ' $t$ ' test was applied to test the significance of these correlation at different levels of significance. Weather fore ast prevailed prior and during the period of peak pest incidence and its influence on the development of the pest were also critically examined.

\section{RESULTS AND DISCUSSION}

\section{Dynamics of S.litura}

Population dynamics of S.litura during different SMWs in soybean at Niphad and in cotton at Rahuri during kharif season are presented in Fig.1(a) and (b). The weekly pheromone trap catches of S.litura in soybean for the years 2009-2014 at Niphad (Fig.1(a)) showed that the pest population was relatively high and above economic threshold level (10 adult/pheromone trap) during 30 to 39 SMWs (from end of July to end of September) in 2012 and 2013. The peak pest population of 120 moths/ trap/week was found in the $32^{\text {nd }}$ SMW (6-12 August) during 2012. It was also noticed that average weekly S.litura population in soybean was above Economic Threshold Level (ETL) of 10 adult moth per trap during the years 2012 and 2009 for most of the weeks and it was below ETL in rest of the years during the period 2009-2014.

In cotton, weekly average pest population was above ETL in most of the years during the period 2004-2009 (Fig. 


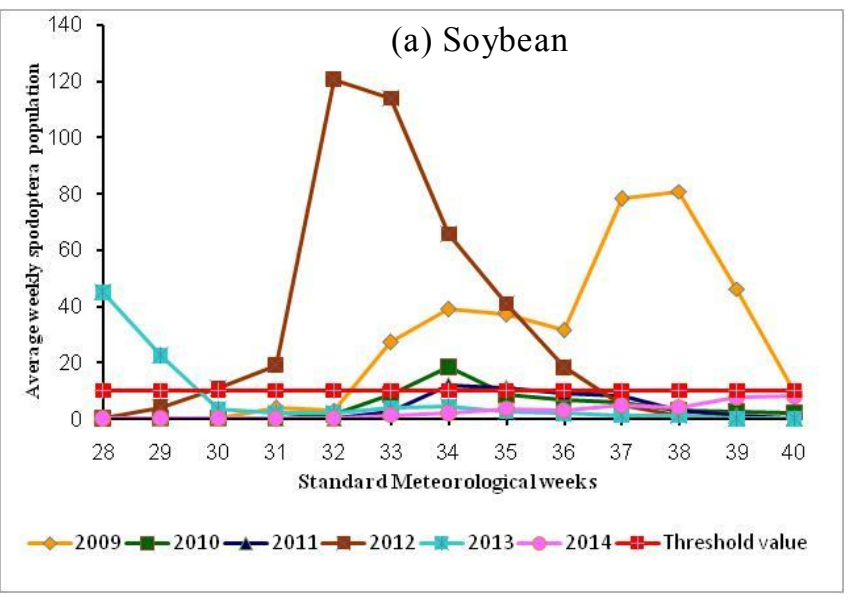

Figs.1 : Seasonal dynamics of Spodoptera litura population in

1(b)). Highest S.litura population of $60 \mathrm{moths} / \mathrm{trap} /$ week was observed in the year 2007 during $40^{\text {th }} \mathrm{SMW}$ ( $1^{\text {st }}$ to $7^{\text {th }}$ October) and pest population was also consistently high in the year 2008 with an average of 30 moths/ trap/week in most of the weeks. Average weekly pest population was less than 5 moths/trap during the years 2004 and 2005. The year to year variation in the pest population could be due to the variation in weather parameters and their impact on reproduction as well as abundance of host crops within the eco system.

\section{Correlation between weather parameters and S. litura}

Correlation coefficients worked out between weekly moth catches of S. litura in soybean and different weather parameters for the week of incidence and at four week lag are given in Table 1. Correlation studies indicated that different weather parameters influenced the pest population differently. The pest population showed positive significant (5\% level) correlation with minimum temperature during the week of incidence and for preceeding four weeks while maximum temperature showed positive correlation (nonsignificant) during the week of incidence and at three- and four-weeks lag periods. Morning relative humiditywas found to be positively correlated (significant at 5\% level) with the pest population during the week of incidence and at one week lag period and negatively correlated at three and four weeks lag periods. Evening humidity showed insignificant positive correlation during the week of incidence as well as preceding two weeks while rainfall was positively and significantly ( $1 \%$ level) correlated with pest population at one week lag period. Bright sunshine hours showed non significant negative correlation with the pest incidence during the week of incidence as well as lag period of previous three weeks with rainfall in all the districts.

Graphical superimposition of pest data for peak pest

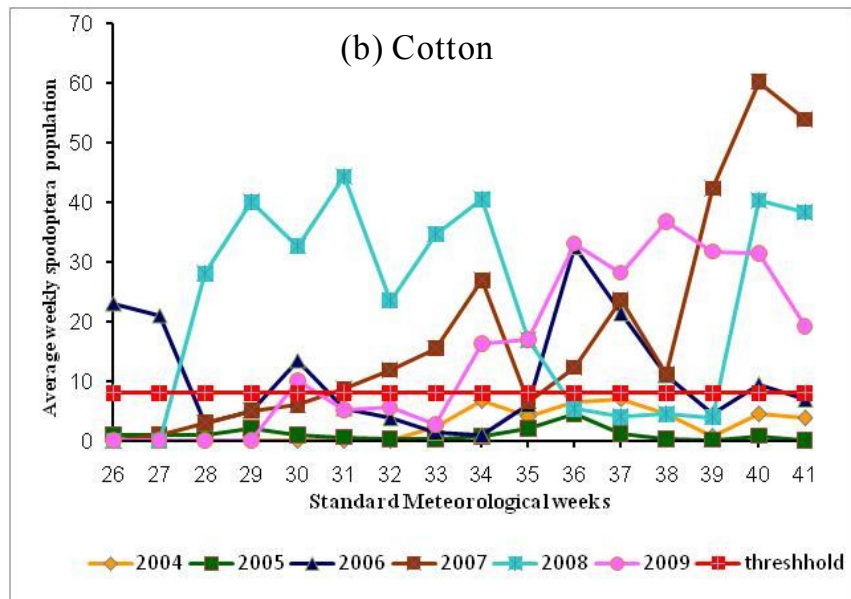

(a) soybean and (b) cotton during kharif season.

incidence and weather parameters were made to work out the critical values conducive for increase in population of the pest. Variation of weather parameters for different weeks and pest population during the year of maximum pest population (2012) and minimum pest incidence in soybean (2011) presented in Fig. 2 (a \&b) showed that critical weather parameters causing the outbreak of S.litura in soybean were maximum temperature around $26-27^{\circ} \mathrm{C}$, minimum temperature around $21-22^{\circ} \mathrm{C}$, morning relative humidity above 90 per cent and occurrence of rainfall during the previous week. It was also observed that cloudy weather (fewer sunshine hours) and rain during the previous week increased the pest population. Rao et.al. (1989) in their study found the occurrence of Spodoptera litura under the lower threshold temperature $\left(10.8^{\circ} \mathrm{C}\right)$ conditions and upper threshold temperature $37^{\circ} \mathrm{C}-40^{\circ} \mathrm{C}$ was found to be lethal for the pest.

Analysis of weather parameters during SMWs 30 to 39 during the year of minimum pest incidence i.e 2011 (Fig.2 (b) ) showed that weekly average maximum temperature varied between $27^{\circ} \mathrm{C}$ to $29.5^{\circ} \mathrm{C}$, minimum temperature $18^{\circ} \mathrm{C}$ to $22^{\circ} \mathrm{C}$, morning relative humidity 90 to 95 per cent, evening humidity 45 to 75 per cent, bright sunshine hours 2 to $8 \mathrm{hrs}$ and weekly total rainfall 0 to $20 \mathrm{~mm}$.

\section{(b) Cotton}

Correlation coefficients worked out between weekly moth catches of S.litura in cotton at Rahuri and different weather parameters for the week of incidence and at four week lag period are given in Table 2. Correlation analysis indicated that maximum temperature during the week of incidence and one week prior to the incidence were found positively correlated (significant at $5 \%$ level) with the pest population while minimum temperature showed non significant negative correlation during the week of incidence and preceding three weeks. The pest population showed 

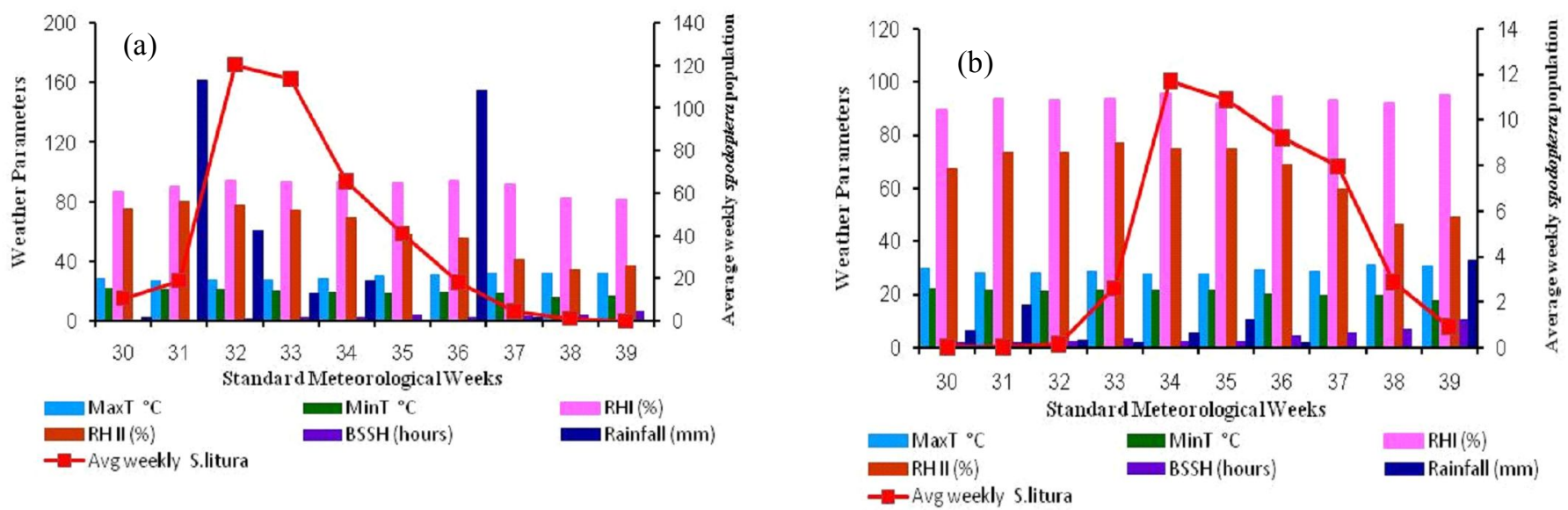

Fig.2(a \&b): Variation of weather parameters during different weeks and S. litura population in soybean at Niphad in the years of maximum (2012) and minimum incidence (2011)

Table 1: Correlation coefficients (CC) between pest population of S. litura in soybean and weather parameters during the week of incidence and for lag periods 1 to 4 at Niphad.

\begin{tabular}{lllllll}
\hline Lag-Period week & Tmax & Tmin & RHI & RHII & BSSH & RF \\
\hline Current & 0.02 & $0.22^{*}$ & $0.23^{*}$ & 0.04 & -0.13 & 0.12 \\
1 week & -0.04 & $0.25^{*}$ & 0.11 & 0.07 & -0.15 & $0.31^{* *}$ \\
2 weeks & -0.07 & $0.29^{*}$ & $-0.32^{* *}$ & 0.05 & $-0.22^{*}$ & 0.12 \\
3 weeks & 0.02 & $0.27^{*}$ & $-0.24^{*}$ & -0.06 & -0.08 & 0.08 \\
4 weeks & 0.14 & $0.23^{*}$ & -0.16 & $-0.23^{*}$ & 0.01 & 0.07 \\
\hline
\end{tabular}

** = significant at $1 \%$ level, $*$ = significant at $5 \%$ level

non significant positive correlation with morning relative humidity during the week of incidence and at four weeks lag while evening humidity showed negative correlation (non significant) during the current week and at one and two week lag periods. Rainfall was found negatively correlated (non significant) with pest population during the week of incidence and up to three week lag periods. Bright Sunshine hours showed non significant positive correlation with the pest incidence during the week of incidence and at one week lag period and negatively correlated during two to four week lag periods. Gedia et.al (2008) reported that the male moths were found active from July to January and attained five peak levels with three oviposition peak with highest moth catch and oviposition in $44^{\text {th }} \mathrm{SMW}$. Also maximum temperature and bright sunshine hour had significant positive while wind speed and rainfall had significant negative association with male moth catches in pheromone trap and oviposition on cotton foliage during the years of study. Dhawan et.al (2009) reported that population dynamics of tobacco caterpillar was positively correlated with the morning relative humidity while it was negatively correlated with the evening relative humidity and mean relative humidity while a positive correlation was found with rainfall for all the distircts.

A critical examination of the variation of weather parameters at different weeks and S.litura population in cotton during the year of maximum pest incidence i.e. 2007 at Rahuri (Fig.3(a) showed that pest population increased substantially with peak pest population during SMW 40 when maximum temperature was around $32-33^{\circ} \mathrm{C}$ and minimum temperature was around $22-23^{\circ} \mathrm{C}$, morning relative humidity was around 90 per cent, sunshine hours were about $6 \mathrm{hrs} /$ day. Maximum temperature, morning relative humidity, bright sunshine hours and rainfall showed slight increasing trend (non significant) while minimum temperature showed significant decreasing trend during the period. Analysis of variation of weather parameters during SMWs 30 to 41 during the year of minimum pest incidence i.e 2005, (Fig.3(b)) showed that weekly average maximum temperature varied between $27^{\circ} \mathrm{C}$ to $32^{\circ} \mathrm{C}$, minimum temperature $18^{\circ} \mathrm{C}$ to $23^{\circ} \mathrm{C}$, morning relative humidity 80 to 90 per cent, evening humidity 40 to 75 per cent, bright sunshine hours 2 to $8 \mathrm{hrs}$ and weekly total rainfall 0 to $120 \mathrm{~mm}$.

\section{Use of synoptic meteorology in pest forecasting}

In order to forecast the incidence of pest well in 

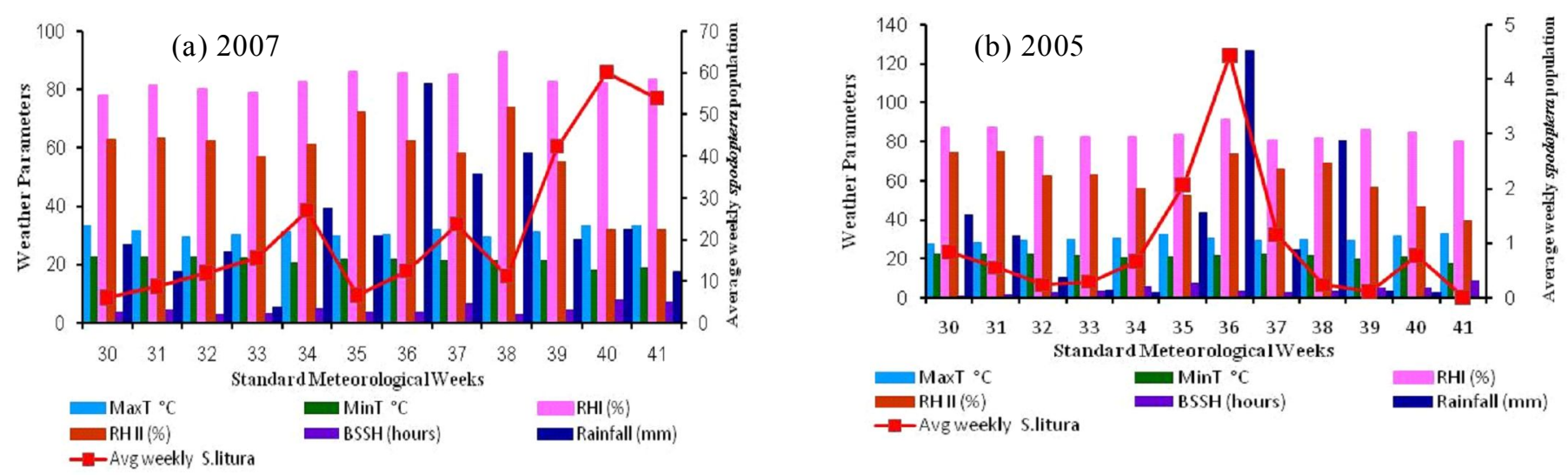

Fig.3(a \&b ): Variation of weather parameters during different weeks and spodptera litura population in the year of maximum (a) and minimum (b) incidence in cotton at Rahuri

Table 2: Correlation coefficients (CC) between population of $S$. litura in cotton and weather parameters during week of incidence and for lag periods of 1 to 4 at Rahuri.

\begin{tabular}{lllllll}
\hline Lag - Period & Tmax & Tmin & RHI & RHII & BSSH & RF \\
\hline week of incidence & $0.32^{* *}$ & -0.08 & 0.07 & $-0.19^{*}$ & 0.15 & -0.02 \\
1 week & $0.18^{*}$ & -0.02 & 0.10 & -0.18 & 0.05 & -0.08 \\
2 weeks & 0.02 & -0.03 & 0.14 & -0.03 & -0.03 & -0.01 \\
3 weeks & -0.06 & -0.02 & 0.14 & 0.07 & -0.15 & 0.04 \\
4 weeks & -0.13 & 0.00 & 0.15 & 0.12 & $-0.22^{*}$ & 0.17 \\
\hline
\end{tabular}

$* *=$ significant at $1 \%$ level $*=$ significant at $5 \%$ level

advance, synoptic meteorology is used as a tool by the agrometeorologists based on the sensitivity of pest incidence to weather parameters. In the present study, the synoptic situations prevailed during the week of peak pest incidence and 2 weeks prior to the peak incidence of S.litura on soybean during 2012 and on cotton during 2007 are presented in Fig. 4 (a-c) and 5(a-c), respectively. Weather charts were examined to find out whether the prevailing weather condition during the week of incidence and two weeks prior to the incidence of the pests on the crop could able to foretell the incidences of the pests. In the year 2012, during two weeks prior to the peak pest incidence $\left(30^{\text {th }}\right.$ SMW) in soybean, the southwest monsoon was subdued over Madhya Maharashtra during the week and at a few places in Madhya Maharashtra received rainfall. Average Maximum temperature during $30^{\text {th }}$ week was $28^{\circ} \mathrm{C}$ and was near normal and minimum temperature was around $22.2^{\circ} \mathrm{C}$ and slightlybelow normal $\left(-1^{\circ} \mathrm{C}\right)$. Morning Relative humidity was around 87 per cent and cloudy conditions prevailed. One week prior to the peak pest incidence ( $31^{\text {st }} \mathrm{SMW}$ ) particularly during the first three days of the week, southwest monsoon was active to vigrous over Madhya Maharashtra and rainfall occurred at most places and the station Niphad received total weekly rainfall of $162.0 \mathrm{~mm}$. Average Maximum temperature during the week was $27^{\circ} \mathrm{C}$ and was below normal by $2{ }^{\circ} \mathrm{C}$ and minimum temperature was around $22^{\circ} \mathrm{C}$ and slightlybelow normal $\left(-1^{\circ} \mathrm{C}\right)$. Morning Relative humidity was around 90 per cent and overcast sky conditions prevailed.

The peak incidence of S. litura in cotton at Rahuri was observed at $40^{\text {th }}$ SMW during the year 2007. During the previous two weeks prior to the peak incidence $\left(38^{\text {th }} \& 39^{\text {th }}\right.$ SMWs), southwest monsoon was active over Madhya Maharashtra and rainfall occurred at many places. During $39^{\text {th }} \mathrm{SMW}$, maximum temperatures was $31^{\circ} \mathrm{C}$, above normal by $2^{\circ} \mathrm{C}$ and minimum temperature was around $21.5^{\circ} \mathrm{C}$, which was normal to slightly below normal $\left(-1^{\circ} \mathrm{C}\right)$. Morning Relative humidity was around 82 per cent and cloudy conditions (BSSH 4.4) prevailed. During $38^{\text {th }}$ SMW, maximum temperatures was $29.5^{\circ} \mathrm{C}$ and minimum temperature was $21.5^{\circ} \mathrm{C}$. Morning Relative humidity was around 93 per cent and cloudy conditions (BSSH 3.1) prevailed (Fig.5a \& 5b). During the peak pest incidence week (SMW40), Madhya Maharshtra received rainfall at a few places on most of the days of the week and Southwest monsoon withdrew from Maharshtra during SMW No.41.

From the above discussion, it appears that it is possible of forewarning the incidence of S. litura in soybean and cotton operationally based on the prevailing synoptic 

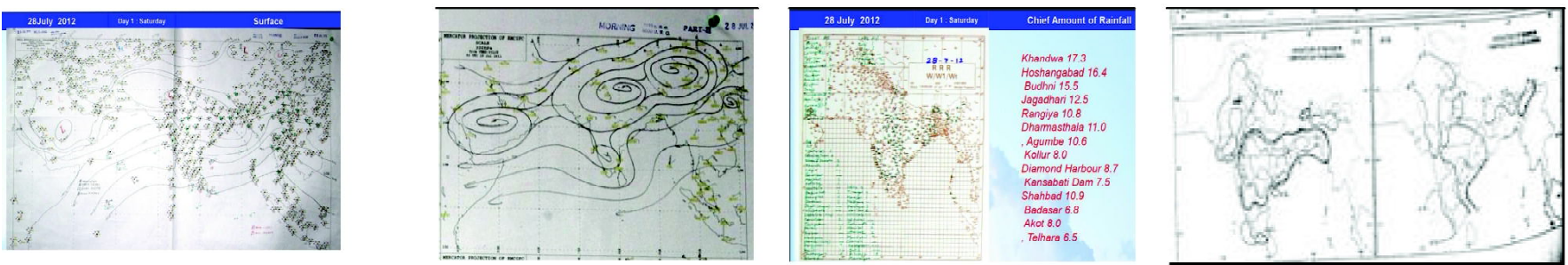

Fig. 4a: Surface chart, upper air chart, rainfall, maximum and minimum temperature departure for $30^{\text {th }}$ week ( 2 weeks prior to the peak pest incidence in soybean) during the year 2012.
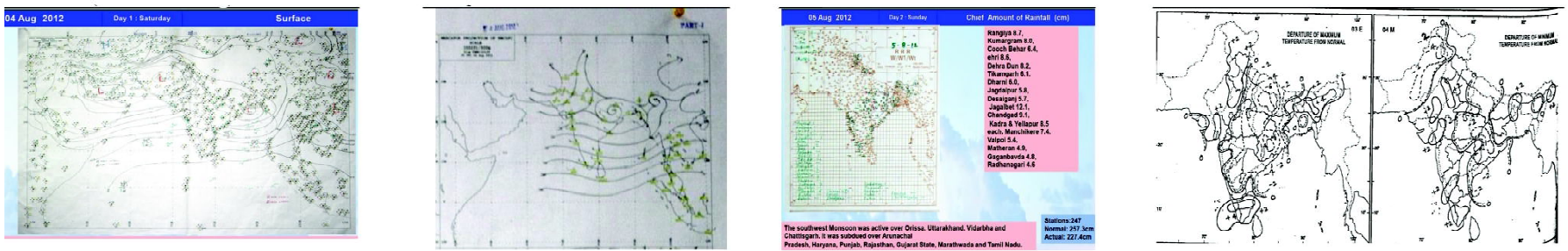

Fig. 4b: Surface chart, upper air chart, rainfall, maximum and minimum temperature departure for $31^{\text {st }}$ week (one week prior to the peak pest incidence in soybean) during the year 2012 .
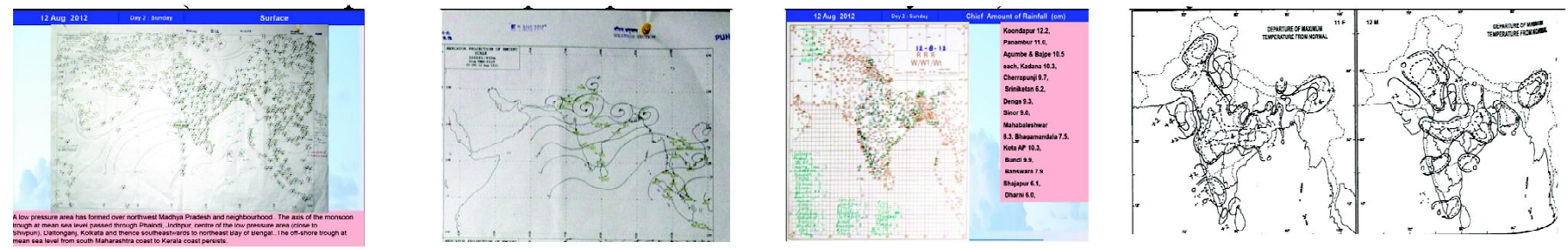

Fig. 4c: Surface chart, upper air chart, rainfall, maximum and minimum temperature departure for $32^{\text {nd }}$ week (the week of peak pest incidence in soybean) during the year 2012.

situations and forecast weather. Maximum temperature in the range of $26-28^{\circ} \mathrm{C}$, minimum temperature $21-22^{\circ} \mathrm{C}$, relative humidity (RHI) 88-90 per cent and cloudy conditions with rainfall for two consecutive weeks during the vegetative to flowering stages of the soybean crop was found to be conducive for incidence of S. litura. Rainfall and cloudy conditions leading to the increase in morning relative humidity (I82 to $90 \%$ ), maximum temperature around 32$33^{\circ} \mathrm{C}$ and minimum temperature below $22-23^{\circ} \mathrm{C}$ during last week of September coinciding with the flowering to boll formation stages in cotton were found congenial for the outbreak of Spodoptera. These thumb rules for forewarning of incidence of pest could be used as tools to frame advisories and can be suitably incorporated in Agromet Advisory Service (AAS) system rendered by the different Agro Meteorological Field Units (AMFUs), which provides a lead time and help in saving on resources of farming community.

\section{CONCLUSIONS}

The study on Spodoptera litura (Tobacco caterpillar) population in soybean and cotton crops in relation to weather parameters during kharif season at Niphad and Rahuri in Maharashtra showed that:

(i) The peak infestation of S.litura in soybean occurred during $32^{\text {nd }}$ to $34^{\text {th }}$ SMWs (second week of August to end of August) and on cotton from $39^{\text {th }}$ to $41^{\text {st }}$ SMWs (end of September to middle of October) coinciding with the vegetation to flowering stages of the crops.

(ii) The correlation analysis showed that the moth catches of S.litura in soybean was positively correlated with Tmax during the week of pest incidence and Tmin during the week of pest incidence as well as four weeks prior to the incidence. Morning and evening humidity were found positively correlated with the pest population one and two weeks prior to the pest incidence and significant positive correlation (at $1 \%$ level) with rainfall was noticed during two weeks prior to the pest incidence. Maximum temperature during the week and one week prior mostly contributed towards the incidence of $S$. litura in cotton. Also morning relative humidity and bright sunshine hours during the week of incidence and at one week lag and rainfall at three and 4 weeks lag period had contributed towards the incidence of 

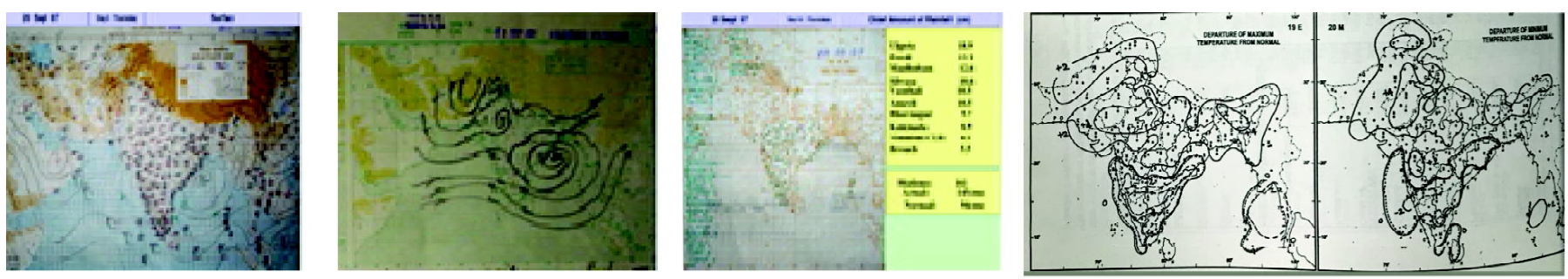

Fig. 5a: Surface chart, upper air chart, rainfall, maximum and minimum temperature departure for $38^{\text {th }}$ SMW ( 2 weeks prior to the peak pest incidence in cotton) during the year 2007.
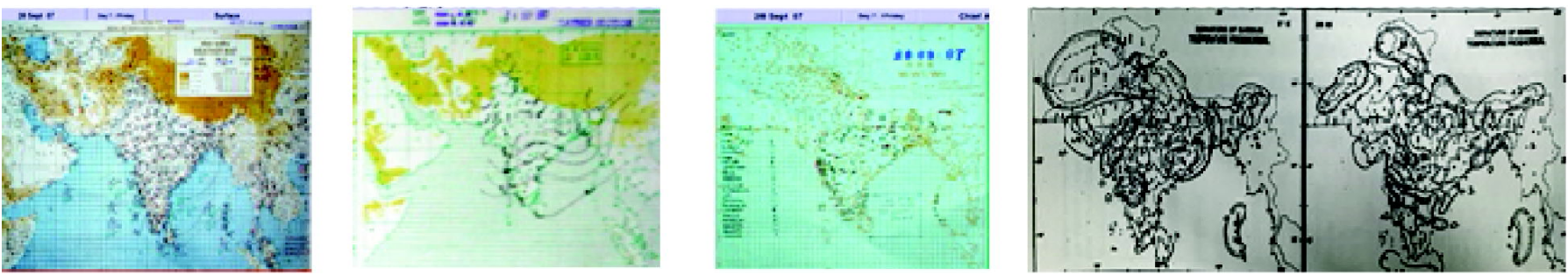

Fig. 5b: Surface chart, upper air chart, rainfall, maximum and minimum temperature departure for $39^{\text {th }}$ SMW(one week prior to the peak pest incidence in cotton) during the year 2007.
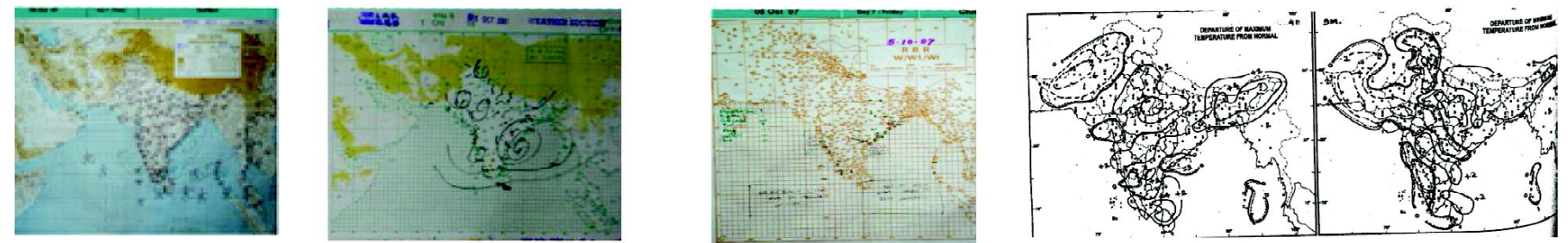

Fig. 5c: Surface chart, upper air chart, rainfall, maximum and minimum temperature departure for $40^{\text {th }}$ SMW (the week of peak pest incidence in cotton) during the year 2007.

\section{S. litura.}

(iii) Graphical Superimposition techniques with peak pest population and weather parameters showed that: maximum and minimum temperature, relative humidity and rainfall during $30^{\text {th }}$ and $31^{\text {st }}$ SMWs played an important role in pest infestation during $32^{\text {nd }}$ SMW in soybean. Critical weather parameters causing the outbreak of Spodoptera in soybean was found to be maximum temperature around $26-27^{\circ} \mathrm{C}$ and minimum temperature around $21-22^{\circ} \mathrm{C}$, morning relative humidity above 90 per cent and rainfall during the previous week. While in cotton, maximum and minimum temperature, relative humidity, rainfall and sunshine hours during $38^{\text {th }}$ and $39^{\text {th }}$ week played an important role in pest infestation during $40^{\text {th }}$ and $41^{\text {st }}$ SMW. Maximum temperature around $32-33^{\circ} \mathrm{C}$ and minimum temperature around $22-23^{\circ} \mathrm{C}$, morning relative humidity around 90 per cent, sunshine hours about $4 \mathrm{hrs} /$ day and rainfall during the previous 2 weeks favoured heavy incidence of Spodoptera litura in cotton crop during flowering to boll formation stages.

(iv) Based on this information including real time weather information and forecasted synoptic conditions, it would be possible to forewarn the incidence of Spodoptera in soybean and cotton.

\section{ACKNOWLEDGEMENTS}

The authors express their thanks to Head, Department of Entomology, Mahatma Phule Krishi Vidyapeeth, Rahuri, Agricultural College and Agriculture Research station Niphad, for their help in providing pest data for soybean and cotton for the study.

\section{REFERENCES}

Mishra A., Das, D. K., Jitendra Singh., Jain, A. K. and Singh, R. (2013). GIS Based Decision Support System of Spodoptera litura (Fabricius). Indian Cartographer, Vol.XXXIII, pp.273-277.

Dhawan, A.K., Anand Aneja., Jasbir, Singh and Sarika, Saini. (2009). Population dynamics of different pests on Btcotton vis-a-vis meteorological parameters in Punjab. J. Agrometeorol., 11 (2): 180-182. 
Gedia, M. V., Vyas H. J. and Acharya M. F. (2008). Weather based monitoring of male moths in pheromone trap and oviposition of Spodoptera litura on cotton in Gujarat. J. Agrometeorol., 10(1) : 81- 85 .

Jha G.K., Gajab Singh., Vennila, S., Srinivas Rao M., Panwar H., and Hegde, M., (2016). Predicting the severity of Spodoptera litura on groundnut in relation to climativ variabilityusing ordinallogistic model.J.Agrometeorol., 18 (2) : 282-287.

Kulkarni, K, A. (1989). Bioecology and management of Spodoptera litura (F.) on groundnut. Arachis hypogaea L. Ph. D Thesis, Univ. Agric. Sci., Dharwad, pp. 79-81.

Nandagopal, V., Prasad, T.V. and Gedia M.V.(2006). Population dynamics of leaf eating caterpillar Spodoptera litura (Fab.) in relation to weather parameters in groundnut in South Saurashtra region. J. Agrometeorol., 8 (1) : 6064.
Rao, G. V.R., J.A.Wightman, andD. V.R. Rao.,(1989). Threshold temperatures and thermal requirements for the development of Spodoptera litura (Lepidoptera: Noctuidae). Environ. Entomol., 18: 548-551.

Selvaraj, S., Adiroubane, D., Ramesh, V. and Narayanan, A. L. (2010). Impact of ecological factors on incidence and development of tobacco cutworm, Spodoptera litura Fabricius on cotton. J. Biopesticides., 3 (1 Special Issue): 43-46.

Senapati, A. K., Das, B. K. and Panda, M. (1990). Influence of weather factors on the catches of male moths of tobacco caterpillar Spodopetra litura $\mathrm{F}$. in the pheromone trap. Environ. Ecol., 8 : 758-760.

Sharma S., Rubaljot Kooner., Sikander Singh Sandhu., Ramesh Arora., Tarundeep Kaur and Simerjeet Kaur. (2017). Seasonal dynamics of insect pests of sugar beet under sub-tropical conditions. J. Agrometeorol., Vol.19 (1) : 81-83. 